\title{
Coupling of Nutrient Removal and Biodiesel Production By Asterarcys quadricellulare Microalga Grown in Municipal Wastewater
}

\author{
Hanaa Morsi \\ Menoufia University \\ Hamed Eladel ( $\nabla$ hamed.hamed@fsc.bu.edu.eg) \\ Benha University https://orcid.org/0000-0002-2369-2965 \\ Ayah Maher \\ Menoufia University
}

\section{Research Article}

Keywords: microalgae, municipal wastewater, lipid, fatty acids, biodiesel

Posted Date: April 28th, 2021

DOI: https://doi.org/10.21203/rs.3.rs-439957/v1

License: (c) (i) This work is licensed under a Creative Commons Attribution 4.0 International License. Read Full License

Version of Record: A version of this preprint was published at BioEnergy Research on September 2nd, 2021. See the published version at https://doi.org/10.1007/s12155-021-10314-z. 


\section{Abstract}

The present study focused on the feasibility of using municipal wastewater (WW) as culture medium for cultivation of microalgae. The study aimed to assess the efficiency of microalgae in nutrients removing capacity from wastewater and its biomass and lipid productivity for using as biodiesel feedstock. Based on that, the green microalga Asterarcys quadricellulare was isolated and grown for 24 days in Bold's Basal Medium as a control and at different concentration of secondary treated municipal wastewater (WW) diluted with distilled water (25\%,50\%, $75 \%$ and $100 \% W W$ ). Results of $75 \%$ WW treatment recorded $96.6 \%$, $98.4 \%$, and $89.9 \%$ removal efficiency for, nitrate, ammonia and total phosphorus, respectively. Also, it revealed high biomass productivity and biomass content, where it recorded $69.0 \mathrm{mgL}^{-1}$ day $^{-1}$, and $1.44 \mathrm{~g} / \mathrm{L}$, respectively. Likewise, high lipid productivity $17.2 \mathrm{mg} \mathrm{L}^{-1} \mathrm{day}^{-1}$ and $360.6 \mathrm{mg} / \mathrm{L}$ lipid content. Consequently, Asterarcys quadricellulare fatty acids profile estimation revealed an increase in Oleic, Palmitic and Linoleic acids levels. Most properties of biodiesel derived from the studied microalga meet with values established by the ASTM D6751 and EN 14214 biodiesel standards. According to this analysis, $A$. quadricellulare microalga could be used for wastewater bioremediation and biomass production with a suitable content of lipids proper as biodiesel feedstock. The predictive biodiesel properties pointed that it has a good quality compared with international standards.

\section{Introduction}

In many parts of the world water environment is beneath stress. For Egypt, water stress value (proportion between renewable water assets and water use) recorded 0.77 in 2004, which appears terrible circumstance agreeing to the United Nations classification [1]. Therefore, it is imperative to seek cost-effective methods and innovative techniques for treatment of wastewater to meet the freshwater demand for human and agriculture use. Long time ago, some researcher used microalgae to treat the effluents from secondary treatment processes to prevent eutrophication [2]. Right now, wastewater treatment using microalgae is an energy-efficient and capable for the removal of pollutants from wastewater as compared to the traditional chemical and physical treatment ways [3]. In wastewater, excess nutrients such as nitrate and phosphate contributes to eutrophication, thereby decreasing dissolved oxygen and increasing the growth of undesired vegetation in the aquatic environment. In addition, microalgae assimilate inorganic carbon from wastewater, which can increase the $\mathrm{pH}$, resulting in ammonia volatilization and phosphorus precipitation [4]. Several earlier studies on nutrients removal efficiency of microalgae from diverse sorts of wastewater [5-8]. These studies suggest feasibility of wastewater treatment using microalgae, which can decrease nutrient cost and water demand while improving water quality.

Due to the broad use of fossil fuels, the world be faced with depletion of energy sources. In this regard, world considered biofuel as renewable alternative to fossil fuels, due to its sustainable features to overcome the global energy demand [9]. Nevertheless, because of their competition with food crops and agricultural lands, biofuel sustainability is often challenged [10]. So, microalgae as renewable source for sustainable biodiesel production is promising due to the ability to store high lipid content (20-75\% wt.) than other oil crops [11], and it does not compete with other agricultural resources [12]. On other hand, although microalgae have great potential as biodiesel feedstock, there are many challenges for commercial application including the extensive freshwater need and the high cost of nutrients [13]. This trouble solved using microalgae cultivation in wastewater which will cut the cost of algae cultivation to make the process of producing biofuel from algae more economic, and environment friendly [14]. municipal wastewater used to substitute synthetic growth media for algal cultivation as an alternative and inexpensive source of nutrients [15]. In addition, the use of microalgae for municipal wastewater treatment and simultaneous lipid accumulation with nutrient removal reaching as high as $90 \%$ and lipid accumulation reaching $28.5 \%$ of dry algal biomass [16]. In order to diminish the reliance on fossil fuel. The study aimed to assess the efficiency of the green microalga purely isolated for nutrients removing capacity from wastewater and its biomass and lipid productivity Also, analyzing its fatty acids profile and assessing its physical-chemical properties for using as biodiesel feedstock.

\section{Materials And Methods}

\section{Microalgae isolation and growth conditions}

Water samples were picked up from different freshwater sources and municipal wastewater treatment plant located in Menoufia, Egypt. Samples were collected in sterilized plastic bottles and transferred to the laboratory shortly after collection. Then, the samples were enriched by using a mixture of $90 \%$ sample and $10 \%$ of cultural Bold's Basal Medium (BBM) [17]. The batch incubation process was carried out for one week, using continuous illumination under white light fluorescent lamps of $80 \mu \mathrm{mol} \mathrm{m} \mathrm{m}^{-2} \mathrm{~s}^{-1}$, at $26 \pm 2{ }^{\circ} \mathrm{C}$ and aerated using a sterile filtered air. After an enrichment period, microalgae growth was visually evaluated using an optical microscope to select the pure microalgae. The tested microalga was isolated, and raised to pure culture through plate technique. Images of the organism were captured through a light microscope. The isolate was propagated in BBM with the earlier growth conditions.

\section{Pretreatment of wastewater}

Secondary treated municipal wastewater samples were collected from the local wastewater plant. Large solid particles were removed by sedimentation and filtration.

\section{Experiments design}

The tested microalga was grown in a conical flask containing $150 \mathrm{~mL}$ of BBM growth medium and incubated under aforementioned growth conditions to be used as the inoculum for the following study experiments. Five $\mathrm{mL}$ were used for inoculation of the experimental flasks containing $150 \mathrm{~mL}$ of different treatments. In arrange to assess the capacity of the isolated microalga and use wastewater as the growth medium for biomass and lipid production, the microalga isolate was cultivated in some blends of wastewater with distilled water. The growth medium (BBM) used as a control, as well as four different concentrations of municipal wastewater diluted using distilled water (25\%,50\%, $75 \%$, and $100 \% \mathrm{WW})$ were inoculated with Asterarcys quadricellulare isolated microalga. All treatments were carried out in triplicate. The samples were withdrawn for analysis every three days' interval. 


\section{Microalga growth assessment}

The study was carried over 24 days, microalga growth was determined by OD (optical density) measurement at $560 \mathrm{~nm}$, and cell counting determined using haemocytometer., chlorophyll (a) was determined by the method adopted by [18]. In addition, cellular dry weight (CDW) was measured initially and after 24 days of incubation. Dry weight was determined according to [19]. Biomass and lipid productivities was calculated according to [20].

\section{Biochemical composition assessment}

Total lipid was determined according to the method described by [21] with modification according to [22]. Protein content determined using the Biuret reaction, adapted by [23]. The total carbohydrate content in the extract was determined by the phenol sulfuric acid method using D-glucose as standard [24].

\section{Assessing of fatty acids profile using GC}

The dry lipid extracts were transesterified to form fatty acid methyl esters (FAME) before being analyzed by gas chromatography [25]. FAMEs were subjected to analysis by gas chromatography using Trace GC1310-ISQ mass spectrometer (Thermo Scientific, Austin, TX, USA) with a direct capillary column TG-5MS (30 $\mathrm{m} \times 0.25 \mathrm{~mm} \times 0.25 \mu \mathrm{m}$ film thickness).

\section{Estimation of biodiesel properties}

Fatty acids percentages of Asterarcys quadricellulare microalga were used to calculate biodiesel properties. Biodiesel properties were estimated according to [26] using "Biodiesel Analyzer@ Ver. 2.2 (available on "http://www.brteam.ir/biodieselanalyzer")

\section{Measurement of Nutrient Removal}

The nutrient medium was separated from the biomass by centrifugation after being filtered through Whatman GF/C filter paper; consumption of ammonia, nitrite, nitrate, phosphate, the biological oxygen demand $\left(\mathrm{BOD}_{5}\right)$, Chemical oxygen demand (COD), electrical conductivity (EC), and total dissolved solid (TDS) by algae at the end of the 24-day growth period were determined. Total phosphate (TP) was measured according to [27], Ammonia nitrogen ( $\mathrm{NH}_{3}-\mathrm{N}$ ), nitrate nitrogen $\left(\mathrm{NO}_{3}-\mathrm{N}\right)$ and biological oxygen demand $\left(\mathrm{BOD}_{5}\right)$ were determined according to [19] and Chemical oxygen demand (COD) was determined according to [28]. Total dissolved solid (TDS) and electrical conductivity (EC) were measured using conductivity bench top meter. Based on the obtained result, the percentage removal efficiency $(\%)$ and removal rate $\left(\mathrm{mg} \mathrm{L}^{-1}\right.$ day $\left.^{-1}\right)$ were calculated according to [8].

\section{Statistical analysis}

All experimental trials were performed in triplicate and the results are presented as the means \pm standard deviation(SD). Statistical analyses were performed using SPSS software 16.0. The comparisons of the mean values were conducted by one-way analysis of variance (ANOVA) followed by a Duncan's new multiple-range test for statistical significance. The differences were considered significant at $(P) \leq 0.05$.

\section{Results And Discussion}

\section{Identification of isolated microalga}

The tested microalga was isolated through streaking on agar plates and sub-culturing in liquid media. Using microscopic characterization, a green microalga (chlorophyta) was morphologically identified as Asterarcys quadricellulare (Fig. 1). It has a unicellular spherical to ovoid form, up to $10 \mu \mathrm{m}$ in diameter, containing a single parietal, sometimes lobed to fragmented chloroplast with a single prominent pyrenoid. Autosporangia containing 2-16 ovoid spores were seen, but no sexual or asexual flagellated stages were observed [29].

\section{Growth of Asterarcys quadricellulare in municipal wastewater}

A. quadricellulare was cultured on BBM as control and different concentrations of secondary treated municipal wastewater (25, 50, 75 and $100 \%$ WW) with its physical and chemical characteristics are presented in Table 1.

Growth was assessed using optical density (OD), chlorophyll (a) content and cells count. The results of microalga growth presented in fig. 2 showed that the least algal growth in $25 \%, 50 \%$ and $100 \%$ WW. Agreement with the study results, $22 \%$ concentration did not increase algal growth, that might be due to the relatively small increase in wastewater concentration. But when used $44 \%$ concentration, cell growth was almost two times higher than $22 \%$ wastewater concentration [30].

Indeed, it was noticed that algae grew faster in the $75 \% \mathrm{WW}$, where it recorded the highest growth as compared with control and the other concentrations. Using pre-treated municipal wastewater $77 \%$ concentration to grow Scenedesmus acutus in batch mode [5]. At 75\%WW optical density, chlorophyll (a), cells count and dry weight recorded the highest values was $1.23,11.12 \mathrm{mg} \mathrm{L}^{-1}, 38.9 \times 10^{4}$ cells $\mathrm{mL}^{-1}$ and $1.44 \mathrm{gL}^{-1}$, respectively. Chlorophyll (a) content is sign of algal growth rate, which increased with time by increasing nutrients removal percent and algal growth biomass [31]. This indicating that $75 \%$ WW is suitable for applications requiring high-density microalga culture when grown in municipal wastewater. Generally, wastewater with high nutrient concentrations could inhibit algal growth, while on the other hand wastewater with low nutrient concentrations could insufficient for algal growth.

\section{Biomass and biochemical composition}


Results for biomass and biochemical composition presented in Table 2 and Fig. 3 showed that biomass productivity of $A$. quadricellulare recorded highest value $69 \mathrm{mgL}^{-1}$ day $^{-1}$ at 75\%WW treatment. These results are consistent with those obtained for some other microalgae [32, 33]. Lipid accumulation by Asterarcys quadricellulare cultivated on different concentrations of municipal wastewater and BBM (control) are presented in Table 2 and Fig. 3 . The results recorded high lipid content with value $360.6 \mathrm{mgL}^{-1}$, lipid productivity $17.2 \mathrm{mgL}^{-1}$ day-1 and lipid yield was $25.3 \%$ for $75 \% \mathrm{WW}$ treatment. The highest lipid accumulation may be due to the highest accumulated biomass from this treatment at the end of growth period. In line with our results several studies were presented in Table 4, Asterarcys quadricellulare microalga produce $0.463 \mathrm{~g} / \mathrm{L}$ lipid, $20 \%$ DW, with lipid productivity of $19.8 \mathrm{mg}^{-\mathrm{L}^{-1} \text { day }}{ }^{-1}$ [34]. Also, Asterarcys sp. showed the greatest biomass productivity $\left(80 \mathrm{mgL}^{-1} \mathrm{~d}^{-1}\right)$ and higher lipid content (30.55\%) [32]. lipid content was $19.4 \%$ after Scenedesmus obliquus cultivation using treated urban wastewater [6]. Scenedesmus acutus had a $28.3 \%$ lipid content on cultivation using pretreated municipal wastewater as the culture medium for 21 days [5].

\section{Nutrients removal}

The removal rates and efficiencies of some nutritional elements from secondary treated municipal wastewater were determined using Asterarcys quadricellulare as presented in Table 3. The result showed that Asterarcys quadricellulare had higher removal rate and efficiency to $\mathrm{NH}_{3}-\mathrm{N}_{\text {and }} \mathrm{NO}_{3}-\mathrm{N}_{\text {, }}$ especially at concentration $75 \% \mathrm{WW}$. The highest $\mathrm{NO}_{3}-\mathrm{N}$ removal rate in $75 \% \mathrm{WW}$ was $0.37 \mathrm{mg} \mathrm{L}^{-1}$ day ${ }^{-1}$ with 4.6 times over control. It also recorded high $\mathrm{NH}_{3}-\mathrm{N}$ removal rate as $0.04 \mathrm{mgL}^{-1}$ day ${ }^{-1}$ indicating 2 times over control. High removal efficiencies $\left(\mathrm{NH}_{3}-\mathrm{N} 98.41 \%, \mathrm{NO}_{3}-\mathrm{N} 96.61 \%\right)$ were recorded at $75 \%$ WW treatment. Removal of NH3-N from the wastewater by algae can be due to direct use as $\mathrm{NH}_{3}-\mathrm{N}$ and/or $\mathrm{NH}_{3}$ stripping [35]. Ammonium is the preferred form of nitrogen for microalgae growth due to its lower energy demand. Nutrient removal can also be increased by $\mathrm{NH}_{3}$ drive out or phosphorus precipitation due to the increasing of the $\mathrm{pH}$ associated with photosynthesis [36].

Regarding phosphorus uptake, the recorded removal efficiency at concentration $75 \%$ WW with a value $89.9 \%$ (Table 3 ). was higher than satisfactory value (80\%) established by European legislation [37]. Removal percentages of this study were closed to that of microalgae grown on mixed municipal and industrial wastewater [38]. The results revealed the ability of Asterarcys quadricellulare to assimilate high amounts of phosphorus and nitrogen for the synthesis of lipid, protein, and carbohydrates of microalga dry weight. The specific nutrient consumption values of $\mathrm{NO}_{3}-\mathrm{N}_{1} \mathrm{NH}_{3}-\mathrm{N}$ and TP by microalga were greater recorded in $75 \%$, while $25 \%$ WW showed the lowest specific consumption (Fig. 4). This is attributed to the higher growth of Asterarcys quadricellulare on $75 \%$ in comparison to other wastewater concentrations and the control growth media.

Both COD and BOD are important in assessing water quality. As wastewater used for the growth of Asterarcys quadricellulare at concentration 75\%WW, COD showed high removal efficiency $84.74 \%$ and removal rate $1.23 \mathrm{mgL}^{-1}$ day $^{-1}$ and BOD with removal efficiency $91.52 \%$ and removal rate $0.38 \mathrm{mgL}^{-1}$ day $^{-1}$ (Table 3). The higher COD and BOD values confirm the greater amount of organic matter. This result showed that Asterarcys quadricellulare prompted increasing the loosing in both BOD and COD values of the effluent and this could be attributed to the increasing of algal growth rate, which implied more photosynthesis happened producing more oxygen. Hence, oxidation of organic matter is improved by released oxygen. Using microalgae in wastewater treatment can increase the removal efficiency of COD [39]. Biological treatment of domestic wastewater using algae indicated 68.4\% BOD and 67.2\% COD removal, respectively [40].

\section{Fatty acids profile}

Lipid assessment results of Asterarcys quadricellulare microalga recorded its high lipid productivity at $75 \%$ WW concentration. Thus, its Fatty acids profile were analyzed using GC and compared to the control (BBM). It was revealed that $A$. quadricellulare fatty acids profile mainly consisting of monounsaturated fatty acid (MUFA), followed by polyunsaturated fatty acid (PUFA) and saturated fatty acid (SAF) shown in Fig. 5 and Table 5. The total MUFA content showed a significant increase in $75 \%$ WW treatment with $23.2 \%$ higher than control and a significant reduction in total PUFA content by $34.37 \%$ below control. The main fatty acids in A. quadricellulare microalga were 16-carbon and 18-carbon, a high proportion of Palmitic acid, Oleic acid and Linoleic acid were found in 75\%WW and control treatments (Table 5). Microalgal lipids which have high proportion of C16:0 and C18:0 fatty acids are proper feedstock for biodiesel production [45,46]. The dominant fatty acids in the microalgae were Palmitic, Stearic and Oleic acids [47]. Thus, this microalga strain is a promising candidate as feedstock for biodiesel production. The increase in the fatty acids (C16-C18) in 75\%WW may refer to the composition balance of this medium.

\section{Biodiesel Properties}

Biodiesel properties of Asterarcys quadricellulare grown in BBM and 75\%WW treatments were determined as shown in Table 6. lodine value is an indicating characteristic of the degree of unsaturation of fatty acid which influences the viscosity and cold filter plugging point. lodine value of control treatment is 84.09 , and of $75 \% W W$ has 77.08. Because the melting point and oxidative stability are related to the degree of unsaturation, The greater the iodine value, the more unsaturation and the higher the susceptibility to oxidation. The lower the iodine value, the better the fuel will be as a biodiesel. Biodiesel with high amounts of saturated fatty acids will have a higher cetane number, while biodiesel with high amounts of unsaturated fatty acids will have a lower CN. Cetane number was 58.66 for control and 58.70 for $75 \%$ WW for Asterarcys quadricellulare biodiesel, it was found to be higher than both the standards ensuring good ignition quality low nitrous oxide emissions, less occurrence of knocking and easier engine start-up [48]. Our results are agreeing with the literature, which report that most properties of biodiesel derived from the studied microalga species already meet with the limit values established by the ASTM D6751 and EN 14214 biodiesel standards $[47,49]$. Also, most of the biodiesel properties represented in Table 6 for Asterarcys quadricellulare in both studied treatments complied with those of another study [43].

\section{Conclusion}


Due to its relatively low organic content, light permeability and the existing mineral nutrients, secondary treated municipal wastewater could be used by microalgae as a low-cost growth medium to produce biomass-based biofuels. As a conclusion nitrogen and phosphorus were efficiently eliminated during the study experiment. The results of the current study indicated the highest percentage of C16-C18 fatty acids (54.92\% from total lipids) at concentration containing a higher part of secondary treated wastewater, which could increase the economical production of the lipid-rich microalgae Asterarcys quadricellulare for biodiesel through saving water and nutrients. Our results offer a primary stage for isolation of microalga species convenient for local conditions, and further studies are needed to enhance the growth and lipid productivity of microalgae grown on wastewater as abundant cheap cultivation medium either in the lab scale and large-scale cultivation conditions.

\section{Declarations}

Funding: This research did not receive any specific grant from funding agencies in the public, commercial, or not-for-profit sectors.

Conflicts of Interest: The authors declare no conflict of interest.

Data availability: All data generated or analysed during this study are included in this published article.

Code availability: Not applicable.

Author Contributions: The authors Hanaa Morsi, Hamed Eladel and Ayah Maher contributed equally to the work.

\section{Acknowledgements}

The authors are grateful to Botany and Microbiology Department, Faculty of Science, Menoufia University, Egypt, for supporting and providing the facilities. Thanks to Dr. Abdallah Saber, for his help in identifying microalga strain.

\section{References}

1. Shakweer A, Youssef RM (2007) Futures studies in Egypt: Water Foresight 2025, Foresight, Vol. 9 Issue 4 pp. $22-32$. https://doi.org/10.1108/14636680710773803

2. Oswald WJ, Lee E, Adan B, Yao K (1978) New wastewater treatment method yields a harvest of 8 saleable algae. WHO chronicle $32: 348$

3. Kumar PK, Krishna SV, Verma K, Pooja K, Bhagawan D, Himabindu V (2018) Phycoremediation of sewage wastewater and industrial flue gases for biomass generation from microalgae. South African journal of chemical engineering 25:133-146. https://doi.org/10.1016/j.sajce.2018.04.006

4. Khan S, Shamshad I, Waqas M, Nawab J, Ming L (2017) Remediating industrial wastewater containing potentially toxic elements with four freshwater algae. Ecol Eng 102:536-541. https://doi.org/10.1016/j.ecoleng.2017.02.038

5. De Alva MS, Luna-Pabello VM, Cadena E, Ortíz E (2013) Green microalga Scenedesmus acutus grown on municipal wastewater to couple nutrient removal with lipid accumulation for biodiesel production. Bioresour Technol 146:744-748. https://doi.org/10.1016/j.biortech.2013.07.061

6. Arbib Z, Ruiz J, Ivarez-Diaz P, Garrido-Pérez C, Perales JA (2014) Capability of different microalgae species for phytoremediation processes: Wastewater tertiary treatment, $\mathrm{CO}_{2}$ bio-fixation and low cost biofuels production. Water Res 49:465-474. https://doi.org/10.1016/j.watres.2013.10.036

7. Rajak U, Nashine P, Verma TN, Pugazhendhi A (2019) Performance, combustion and emission analysis of microalgae Spirulina in a common rail direct injection diesel engine. Fuel 255:115855. https://doi.org/10.1016/j.fuel.2019.115855

8. Eladel H, Abomohra AE, Battah M, Mohmmed S, Radwan A, Abdelrahim H (2019) Evaluation of Chlorella sorokiniana isolated from local municipal wastewater for dual application in nutrient removal and biodiesel production. Bioprocess Biosyst Eng 42(3):425-433. https://doi.org/10.1007/s00449018-2046-5

9. Adeniyi OM, Azimov U, Burluka A (2018) Algae biofuel: Current status and future applications. Renewable sustainable energy reviews 90:316-335. https://doi.org/10.1016/j.rser.2018.03.067

10. Mishra A, Medhi K, Maheshwari N, Srivastava S, Thakur IS (2018) Biofuel production and phycoremediation by Chlorella sp. ISTLA1 isolated from landfill site. Bioresour Technol 253:121-121. https://doi.org/10.1016/j.biortech.2017.12.012

11. Amaro HM, Guedes AC, Malcata FX (2011) Advances and Perspectives in Using Microalgae to Produce Biodiesel. Appl Energy 88:3402-3410. https://doi.org/10.1016/j.apenergy.2010.12.014

12. Jones CS, Mayfieldt SP (2012) Algae Biofuels: versatility for the Future of Bioenergy. Curr Opin Biotechnol 23(3):346-351. https://doi.org/10.1016/j.copbio.2011.10.013

13. Abomohra A, Jin W, Tu R, Han SF, Eid M, Eladel H (2016) Microalgal biomass production as a sustainable feedstock for biodiesel: current status and perspectives. Renew Sustain Energy Rev 64:596-606. https://doi.org/10.1016/j.rser.2016.06.056

14. Wang JH, Zhuang LL, Xu XQ, Deantes-Espinosa VM, Wang XX, Hu HY (2018) Microalgal attachment and attached systems for biomass production and wastewater treatment. Renew Sustain Energy Rev 92:331-342. https://doi.org/10.1016/j.rser.2018.04.081

15. Ji MK, Abou-Shanab RA, Kim SH, Salama ES, Lee SH, Kabra AN, ... Jeon BH (2013) Cultivation of microalgae species in tertiary municipal wastewater supplemented with $\mathrm{CO}_{2}$ for nutrient removal and biomass production. Ecol Eng 58:142-148. https://doi.org/10.1016/j.ecoleng.2013.06.020

16. Mahapatra DM, Chanakya HN, Ramachandra TV (2014) Bioremediation and lipid synthesis through mixotrophic algal consortia in municipal wastewater. Bioresour Technol 168:142-150. https://doi.org/10.1016/j.biortech.2014.03.130 
17. Bischoff HW, Bold HC (1963) Phycological studies: some soil algae from enchanted rock and related algal species, 6318. University of Texas Publications, Austin, pp 1-95

18. Lichtenthaler HK, Buschmann C (2001) Chlorophylls and carotenoids: Measurements and characterization by UV-VIS spectroscopy. Curr Prot Food Analyt Chem F. . https://doi.org/10.1002/0471142913.faf0403s01

19. APHA (2005) Standard methods for the examination of water and wastewater, 21 st edn. American Public Health Association, Washington, DC

20. Abomohra A, Wagner M, El-Sheekh M, Hanelt D (2013) Lipid and total fatty acid productivity in photoautotrophic freshwater microalgae: screening studies towards biodiesel production. J Appl Phycol 25(4):931-936. https://doi.org/10.1007/s10811-012-9917-y

21. Bligh EG, Dyer WJ (1959) A rapid method of total lipid extraction and purification. Canadian journal of biochemistry physiology 37(8):911-917. https://doi.org/10.1139/059-099

22. Lee CM, Trevino B, Chaiyawat M (1996) A simple and rapid solvent extraction method for determining total lipids in fish tissue. J AOAC Int 79(2):487492. https://doi.org/10.1093/jaoac/79.2.487

23. Lowry OH, Rosebrough NJ, Farr AL, Randall RJ (1951) Protein Measurement with the Folin Phenol Reagent. J Biol Chem 193:265-275. https://doi.org/10.1016/S0021-9258(19)52451-6

24. Dubois M, Gilles KA, Hamilton JK, Rebers PT, Smith F (1956) Colorimetric method for determination of sugars and related substances. Analytical chemistry 28(3):350-356. https://doi.org/10.1021/ac60111a017

25. Luddy FE, Barford RA, Riemenschneider RW (1960) Direct conversion of lipid components to their fatty acid methyl esters. J Am Oil Chem Soc 37(9):447451. https://doi.org/10.1007/BF02631205

26. Talebi AF, Tabatabaei M, Chisti Y (2014) BiodieselAnalyzer@: a user-friendly software for predicting the properties of prospective biodiesel. Biofuel Research Journal 55-57. https://doi.org/10.18331/BRJ2015.1.2.4

27. Woods J, Mellon M (1941) The molybdenum blue reaction: a spectrophotometric study. Ind Eng Chem Anal Ed 13:760-764. https://doi.org/10.1021/i560099a003

28. Mancy KH (1971) Instrumental analysis for water pollution control. Ann Arbor Science Publishers, Inc., Ann Arbor

29. Saber AA, Fučíková K, McManus HA, Guella G, Cantonati M (2018) Novel green algal isolates from the Egyptian hyper-arid desert oases: a polyphasic approach with a description of Pharao desertorum gen. et sp. nov. (Chlorophyceae, Chlorophyta). J Phycol. 54(3):342-357. https://doi.org/10.1111/jpy.12645

30. Sousa LL, Dominique SH, Emerson AS, Louisa WP (2014) Cultivation of Nannochloropsis sp. in brackish groundwater supplemented with municipal wastewater as a nutrient source. Brazilian Archives of Biology Technology 57(2):171-177. https://doi.org/10.1590/S1516-89132014000200003

31. Fried S, Mackie B, Nothwehr E (2003) Nitrate and phosphate levels positively affect the growth of algae species found in Perry Pond. Tillers 4:21-24

32. Sangapillai K, Marimuthu T (2019) Isolation and selection of growth medium for freshwater microalgae Asterarcys quadricellulare for maximum biomass production. Water Sci Technol 80(11):2027-2036. https://doi.org/10.2166/wst.2020.015

33. Zili F, Bouzidi N, Ammar J, Zakhama W, Ghoul M, Sayadi S, Ouada HB (2017) Mixotrophic cultivation promotes growth, lipid productivity, and PUFA production of a thermophilic Chlorophyta strain related to the genus Graesiella. J Appl Phycol 29(1):35-43. https://doi.org/10.1007/s10811-016-0941-1

34. Octávio O, Sônia G, Vânia S, Teresa M, Nídia C (2017) Lipid and carbohydrate profile of a microalga isolated from wastewater. Energy Procedia 136:468473. https://doi.org/10.1016/j.egypro.2017.10.305

35. Tam NFY, Wong YS (1989) Wastewater nutrient removal by Chlorella pyrenoidosa and Scenedesmus sp. Environ Pollut 58:19-34. https://doi.org/10.1016/0269-7491(89)90234-0

36. Oswald WJ (1988) Micro-algae and wastewater treatment. Microalgal biotechnology 305-328

37. Bloch H (2005) European Union legislation on wastewater treatment and nutrients removal. Foundation for Water Research, UK

38. Francesco GG (2014) Microalgal biomass and lipid production in mixed municipal, dairy, pulp and paper wastewater together with added flue gases. Bioresour Technol 169:27-32. https://doi.org/10.1016/j.biortech.2014.06.061

39. Rothermel MC (2011) "Coupling the wastewater treatment process with an algal photobioreactor for nutrient removal and renewable resource production." PhD diss. University of Pittsburgh

40. Aslan S, Kapdan IK (2006) Batch kinetics of nitrogen and phosphorus removal from synthetic wastewater by algae. Ecol Eng $28: 64-70$. https://doi.org/10.1016/j.ecoleng.2006.04.003

41. Varshney P, Beardall J, Bhattacharya S, Wangikar PP (2018) Isolation and biochemical characterisation of two thermophilic green algal speciesAsterarcys quadricellulare and Chlorella sorokiniana, which are tolerant to high levels of carbon dioxide and nitric oxide. Algal research 30:28-37. https://doi.org/10.1016/j.algal.2017.12.006

42. Hong JW, Kim S, Chang JW, Yi J, Jeong JE, Kim SH, Kim SH, Yoon HS (2012) Isolation and description of a Korean microalga, Asterarcys quadricellulare KNUA020, and analysis of its biotechnological potential. Algae 27(3):197-203. https://doi.org/10.4490/algae.2012.27.3.197

43. Do J-M, Jo S-W, Kim I-S, Na H, Lee JH, Kim HS, Yoon H-SA (2019) Feasibility Study of Wastewater Treatment Using Domestic Microalgae and Analysis of Biomass for Potential Applications. Water 11:2294. https://doi.org/10.3390/w11112294

44. Han S, Jin W, Chen Y, Tu R, Abomohra A (2016) Enhancement of lipid production of Chlorella pyrenoidosa cultivated in municipal wastewater by magnetic treatment. Appl Biochem Biotechnol 180:1043-1055. https://doi.org/10.1007/s12010-016-2151-3

45. Knothe G (2008) Optimizing fatty ester composition to improve fuel properties. Energy Fuels 22:1358-1364. https://doi.org/10.1021/ef700639e 
46. Diaz GC, Cruz YR, Fortes MM, Viegas CV, Carliz RG, Furtado NC, Aranda DG (2014) Primary separation of antioxidants (unsaponifiables) the wet biomass microalgae Chlamydomonas sp and production biodiesel. Nat Sci 6:1210-1218. https://doi.org/10.4236/ns.2014.615108

47. Odjadjare EC, Mutanda T, Chen Y, Olaniran AO (2018) Evaluation of Pre-Chlorinated Wastewater Effluent for Microalgal Cultivation and Biodiesel Production. Water 10(8):977. https://doi.org/10.3390/w10080977

48. Demirbas A (2005) Biodiesel production from vegetable oils via catalytic and non-catalytic supercritical methanol transesterification methods. Prog Energ Combust 31:466-487. https://doi.org/10.1016/j.pecs.2005.09.001

49. Kaur S, Sarkar M, Srivastava RB, Gogoi HK, Kalita MC (2012) Fatty acid profiling and molecular characterization of some freshwater microalgae from India with potential for biodiesel production. New Biotechnology 29(3):332-344. https://doi.org/10.1016/j.nbt.2011.10.009

\section{Tables}

Table 1 Physico-chemical characteristics of secondary treated municipal wastewater, and obtained from a local municipal wastewater treatment plant used in this study

\begin{tabular}{|c|c|}
\hline Parameters & Value \\
\hline $\mathrm{pH}$ & 7.6 \\
\hline Temperature & 26 \\
\hline $\mathrm{NO}_{3} \mathrm{mgL}^{-1}$ & 9.098 \\
\hline $\mathrm{TP}_{\mathrm{mgL}} \mathrm{L}^{-1}$ & 1.390 \\
\hline $\mathrm{NH}_{3} \mathrm{mgL}^{-1}$ & 0.870 \\
\hline $\mathrm{BOD}_{5}\left(\mathrm{mgL}^{-1}\right)$ & 12.167 \\
\hline $\operatorname{COD}\left(\mathrm{mgL}^{-1}\right)$ & 44.670 \\
\hline $\operatorname{TDS}\left(\mathrm{mgL}^{-1}\right)$ & 520.30 \\
\hline $\mathrm{EC}(\mu \mathrm{mhos} / \mathrm{cm})$ & 1106 \\
\hline
\end{tabular}

Table 2 Biomass and biochemical composition of A. quadricellulare grown for 24 days in BBM as control and different municipal wastewater concentrations $(25 \%, 50 \%, 75 \%$ and $100 \% W W)$

\begin{tabular}{|c|c|c|c|c|c|}
\hline Parameters & BBM & $25 \% W W$ & $50 \% W W$ & $75 \% W W$ & $100 \%$ WW \\
\hline Biomass (Dry weight gL ${ }^{-1}$ ) & $1.29 \pm 0.014^{\mathrm{B}}$ & $0.74 \pm 0.045^{\mathrm{D}}$ & $0.99 \pm 0.039^{C}$ & $1.44 \pm 0.055^{\mathrm{A}}$ & $1.30 \pm 0.061^{\mathrm{B}}$ \\
\hline Biomass productivity $\mathrm{mgL}^{-1}$ day $^{-1}$ & $62 \pm 0.003^{B}$ & $35 \pm 0.002^{D}$ & $47 \pm 0.001^{\mathrm{C}}$ & $69 \pm 0.002^{A}$ & $62 \pm 0.001^{B}$ \\
\hline Lipid content $\mathrm{mgL}^{-1}$ & $317.0 \pm 0.319^{B}$ & $163.0 \pm 0.659^{D}$ & $213.7 \pm 0.563^{C}$ & $360.6 \pm 0.659^{A}$ & $328.7 \pm 1.354^{\mathrm{B}}$ \\
\hline Lipid productivity $\mathrm{mgL}^{-1}$ day $^{-1}$ & $15.1 \pm 0.218^{A}$ & $7.8 \pm 0.297^{D}$ & $11.9 \pm 0.402^{C}$ & $17.2 \pm 0.262^{B}$ & $15.2 \pm 0.120^{\mathrm{AB}}$ \\
\hline Lipid yield (\% CDW) & $24.5 \pm 0.319^{A}$ & $22.2 \pm 0.659^{B}$ & $21.6 \pm 0.563^{B}$ & $25.3 \pm 1.354^{\mathrm{A}}$ & $25.0 \pm 0.659^{A}$ \\
\hline Protein yield (\% CDW) & $31.4 \pm 0.111^{\mathrm{A}}$ & $27.9 \pm 1.352^{\mathrm{B}}$ & $27.8 \pm 0.650^{B}$ & $31.1 \pm 1.469^{\mathrm{A}}$ & $32.3 \pm 1.288^{\mathrm{A}}$ \\
\hline Carbohydrate yield (\% CDW) & $31.049 \pm 0.209^{A}$ & $27.035 \pm 1.684^{\mathrm{B}}$ & $24.370 \pm 0.704^{B}$ & $26.826 \pm 1.287^{\mathrm{B}}$ & $30.427 \pm 1.466^{\mathrm{A}}$ \\
\hline
\end{tabular}

Each value is the mean of three replicates \pm SD

Values of the same raw with the same small letter showed insignificant differences (at $P \leq 0.05$ )

Table 3 Nutrient removal rate (RR, $\mathrm{mgL}^{-1}$ day $^{-1}$ ) and removal efficiency (RE, \%) of Asterarcys quadricellulare grown for 24 days in BBM and different municipal wastewater concentrations 


\begin{tabular}{|c|c|c|c|c|c|c|c|c|c|c|}
\hline \multirow[t]{2}{*}{ parameters } & \multicolumn{2}{|c|}{$\underline{\text { Control (BBM). }}$} & \multicolumn{2}{|l|}{$25 \%$ WW } & \multicolumn{2}{|l|}{$\underline{50 \% W W}$} & \multicolumn{2}{|l|}{$\underline{75 \% W W}$} & \multicolumn{2}{|l|}{$100 \%$ WW } \\
\hline & $\mathrm{RR}$ & $\mathrm{RE} \%$ & RR & RE\% & RR & RE\% & $\mathrm{RR}$ & RE\% & $\mathrm{RR}$ & $\mathrm{R}$ \\
\hline $\begin{array}{l}\text { EC } \\
\text { ( } \mu \mathrm{mhos})\end{array}$ & $7.48 \pm 0.13^{\mathrm{D}}$ & $61.37 \pm 1.63^{a}$ & $3.34 \pm 0.35^{\mathrm{E}}$ & $27.16 \pm 2.50^{d}$ & $8.36 \pm 0.18^{C}$ & $37.11 \pm 0.89^{c}$ & $16.73 \pm 0.22^{\mathrm{B}}$ & $45.37 \pm 1.15^{a}$ & $19.22 \pm 0.54^{\mathrm{A}}$ & 41 \\
\hline $\begin{array}{l}\text { TDS (mgL- } \\
\left.{ }^{1}\right)\end{array}$ & $4.30 \pm 0.08^{\mathrm{D}}$ & $65.35 \pm 2.07^{a}$ & $2.62 \pm 0.05^{\mathrm{E}}$ & $41.13 \pm 1.80^{d}$ & $5.58 \pm 0.04^{C}$ & $49.69 \pm 1.06^{c}$ & $10.64 \pm 0.23^{B}$ & $63.34 \pm 1.18^{a}$ & $13.19 \pm 0.12^{\mathrm{A}}$ & $5 i$ \\
\hline $\begin{array}{l}\mathrm{NO}_{3}\left(\mathrm{mgL}^{-}\right. \\
\left.{ }^{1}\right)\end{array}$ & $0.08 \pm 0.00^{\mathrm{D}}$ & $92.96 \pm 1.20^{\mathrm{b}}$ & $0.09 \pm 0.01^{\mathrm{D}}$ & $76.76 \pm 2.88^{d}$ & $0.19 \pm 0.00^{C}$ & $87.18 \pm 1.48^{c}$ & $0.37 \pm 0.01^{B}$ & $96.61 \pm 3.05^{a}$ & $0.31 \pm 0.00^{\mathrm{A}}$ & 9: \\
\hline $\begin{array}{l}\mathrm{NH}_{3}\left(\mathrm{mgL}^{-}\right. \\
\left.{ }^{1}\right)\end{array}$ & $0.02 \pm 0.00^{\mathrm{E}}$ & $94.20 \pm 1.51^{\mathrm{b}}$ & $0.01 \pm 0.00^{\mathrm{D}}$ & $77.48 \pm 2.078^{d}$ & $0.01 \pm 0.00^{C}$ & $89.53 \pm 1.08^{c}$ & $0.04 \pm 0.00^{\mathrm{B}}$ & $98.41 \pm 2.02^{\mathrm{a}}$ & $0.03 \pm 0.00^{A}$ & 91 \\
\hline $\mathrm{TP}\left(\mathrm{mgL}^{-1}\right)$ & $0.06 \pm 0.00^{\mathrm{A}}$ & $85.85 \pm 1.94^{\mathrm{a}}$ & $0.01 \pm 0.00^{\mathrm{D}}$ & $53.07 \pm 3.844^{c}$ & $0.02 \pm 0.00^{C}$ & $72.86 \pm 1.57^{b}$ & $0.05 \pm 0.00^{\mathrm{B}}$ & $89.87 \pm 1.83^{a}$ & $0.04 \pm 0.00^{A}$ & 8 \\
\hline $\begin{array}{l}\mathrm{BOD}_{5} \\
\left(\mathrm{mgL}^{-1}\right)\end{array}$ & $0.27 \pm 0.02^{C}$ & $83.42 \pm 3.21^{\mathrm{a}}$ & $0.08 \pm 0.02^{\mathrm{E}}$ & $57.52 \pm 4.72^{\mathrm{c}}$ & $0.19 \pm 0.02^{\mathrm{D}}$ & $66.87 \pm 2.09^{b}$ & $0.38 \pm 0.02^{B}$ & $91.52 \pm 1.16^{\mathrm{a}}$ & $0.41 \pm 0.03^{\mathrm{A}}$ & 8 \\
\hline $\begin{array}{l}\mathrm{COD}\left(\mathrm{mgL}^{-}\right. \\
\left.{ }^{1}\right)\end{array}$ & $1.40 \pm 0.02^{\mathrm{B}}$ & $87.17 \pm 1.92^{\mathrm{a}}$ & $0.38 \pm 0.03^{\mathrm{E}}$ & $62.27 \pm 4.39^{b}$ & $0.73 \pm 0.04^{\mathrm{D}}$ & $68.35 \pm 3.40^{b}$ & $1.23 \pm 0.03^{C}$ & $84.74 \pm 1.96^{a}$ & $1.48 \pm 0.03^{\mathrm{A}}$ & 8: \\
\hline
\end{tabular}

Table 4 Comparison of the results obtained in the present study with previously reported work for microalgae cultivated in different effluents of wastewater

\begin{tabular}{|c|c|c|c|c|c|c|c|c|}
\hline \multirow[t]{2}{*}{ Microalgae } & \multirow[t]{2}{*}{ Medium } & \multirow[t]{2}{*}{$\mathrm{Bp}^{\mathrm{a}}$} & \multirow[t]{2}{*}{$\mathrm{LP}^{\mathrm{b}}$} & \multicolumn{4}{|c|}{ Nutrient removal efficiency (\%) } & \multirow[t]{2}{*}{ Reference } \\
\hline & & & & $\mathrm{NO}_{3}-\mathrm{N}$ & $\mathrm{NH}_{3}-\mathrm{N}$ & TP & COD & \\
\hline Asterarcys quadricellulare & Municipal wastewater & 69 & 17.2 & 96.6 & 98.4 & 89.9 & 84.7 & This study \\
\hline Asterarcys quadricellulare & $\mathrm{BBM}+0.1 \mathrm{~g} / \mathrm{L}$ glucose & - & 19.8 & $(48)^{\mathrm{TN}}$ & - & 50 & 12.4 & [34] \\
\hline Asterarcys quadricellulare & BBM & - & 44 & - & - & - & - & [41] \\
\hline Asterarcys quadricellulare & Modified BBM & 57.7 & 15 & - & - & - & - & [32] \\
\hline Asterarcys quadricellulare & BG-11 media & - & 15.5 & - & - & - & - & {$[42]$} \\
\hline Asterarcys quadricellulare & Municipal wastewater & - & - & $(52)^{\mathrm{TN}}$ & 99.1 & 95.7 & - & [43] \\
\hline Chlorella sorokiniana & Municipal wastewater & 73 & 16.2 & 74.2 & 83.3 & 78.0 & 61.9 & [8] \\
\hline Chlorella pyrenoidosa & Municipal wastewater & 229 & 48.90 & - & 59.4 & 93.8 & 76.9 & {$[44]$} \\
\hline
\end{tabular}

TN total nitrogen

a Biomass productivity calculated as $\mathrm{mg} \mathrm{L}^{-1}$ day

${ }^{\mathrm{b}}$ Lipid productivity calculated as $\mathrm{mg} \mathrm{L}^{-1}$ day

Table 5 Fatty acids composition (\% fatty acids) of Asterarcys quadricellulare grown for 24 days in control (BBM), and 75\%WW treatments. 


\begin{tabular}{|lll|}
\hline Fatty Acids & Control & $75 \%$ WW \\
\hline Saturated fatty acids (SFA) & & \\
\hline Palmitic acid (C16:0) & 18.31 & 20.54 \\
\hline Stearic acid (C18:0) & 0.64 & 0.59 \\
\hline Monounsaturated fatty acids (MUFA) & \\
\hline Oleic acid (C18:1) & 44.57 & 54.92 \\
\hline Polyunsaturated fatty acids (PUFA) & \\
\hline Hexadecadienoic acid (C16:2) & 3.92 & 2.22 \\
\hline Linoleic acid (C18:2) & 20.29 & 13.38 \\
\hline Hexadecatrienoic acid (C16:3) & 8.22 & 6.49 \\
\hline Linolenic acid (C18:3) & 0.77 & - \\
\hline Hexadecatetraenoic acid (C16:4) & 1.90 & 0.91 \\
\hline Stearidonic acid (C18:4) & 1.40 & 0.94 \\
\hline SAT & 18.95 & 21.13 \\
\hline MUFA & 44.57 & 54.92 \\
\hline PUFA & 36.49 & 23.95 \\
\hline Total & 100.00 & 100.00 \\
\hline
\end{tabular}

Table 6 Biodiesel properties based on fatty acid profile of Asterarcys quadricellulare grown in (BBM) and $75 \%$ WW for 24 days, compared to othr study and international standards

\begin{tabular}{|c|c|c|c|c|c|}
\hline \multirow[t]{2}{*}{ Biodiesel properties } & \multicolumn{2}{|c|}{$\begin{array}{l}\text { Asterarcys quadricellulare } \\
\text { This study }\end{array}$} & \multirow[t]{2}{*}{ Asterarcys quadricellulare [43] } & \multicolumn{2}{|c|}{ Biodiesel standards } \\
\hline & Control & $75 \% W W$ & & ASTM & CEN \\
\hline Degree of Unsaturation (DU) & 89.49 & 83.56 & 102 & - & - \\
\hline Saponification Value $(\mathrm{mg} / \mathrm{g})(\mathrm{SV})$ & 174.51 & 183.52 & 179 & - & - \\
\hline lodine Value (gl/100g) (IV) & 84.09 & 77.08 & 131 & - & Less 120 \\
\hline Cetane number ( $\mathrm{CN}$ ) & 58.66 & 58.70 & 44.7 & Above 47 & Above 51 \\
\hline Long Chain Saturated Factor (LCSF) & 2.15 & 2.35 & 3.0 & - & - \\
\hline Cold Filter Plugging Point $\left({ }^{\circ} \mathrm{C}\right)(\mathrm{CFPP})$ & -9.72 & -9.10 & -7.0 & -5 to -13 & 5 to -20 \\
\hline Cloud Point $\left({ }^{\circ} \mathrm{C}\right)(\mathrm{CP})$ & 4.64 & 5.81 & - & & 4 \\
\hline Pour Point $\left({ }^{\circ} \mathrm{C}\right)(\mathrm{PP})$ & -1.79 & -0.51 & - & -15 to 10 & \\
\hline Allylic Position Equivalent (APE) & 89.49 & 83.56 & - & - & \\
\hline Bis-Allylic Position Equivalent (BAPE) & 21.83 & 13.38 & - & - & \\
\hline Oxidation Stability (h) (OS) & 8.19 & 11.40 & 6.8 & 3 & 6 \\
\hline Higher Heating Value (HHV) & 33.93 & 35.68 & - & - & \\
\hline Kinematic Viscosity $\left(\mathrm{mm}^{2} / \mathrm{s}\right)(\mathrm{U})$ & 3.15 & 3.41 & 3.76 & $1.9-6$ & $3.5-5$ \\
\hline Density $\left(\mathrm{g} / \mathrm{cm}^{3}\right)(\rho)$ & 0.75 & 0.79 & 0.88 & 0.88 & $0.86-0.90$ \\
\hline
\end{tabular}

\section{Figures}




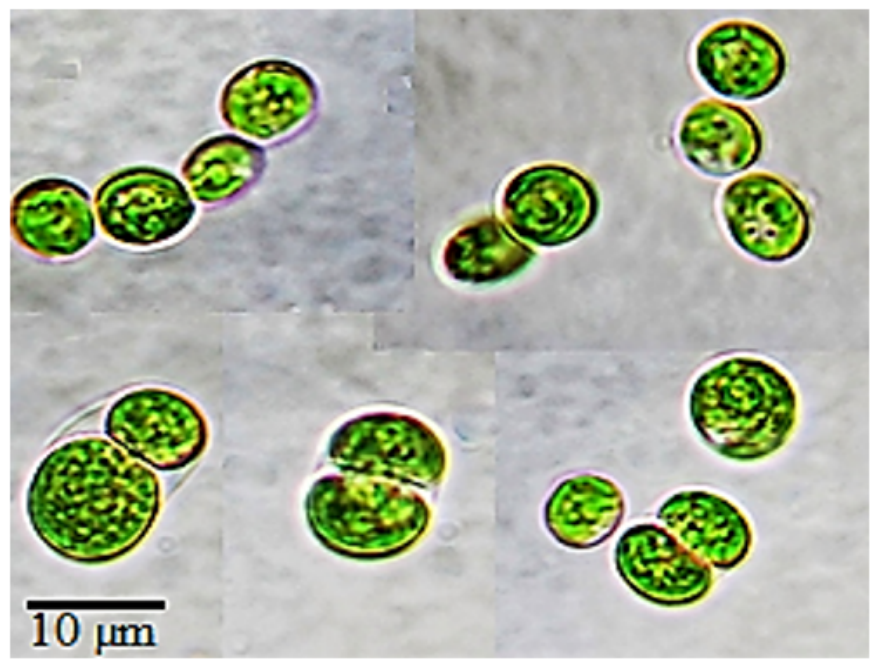

Figure 1

Photomicrograph (X400) of the green microalga Asterarcys quadricellulare
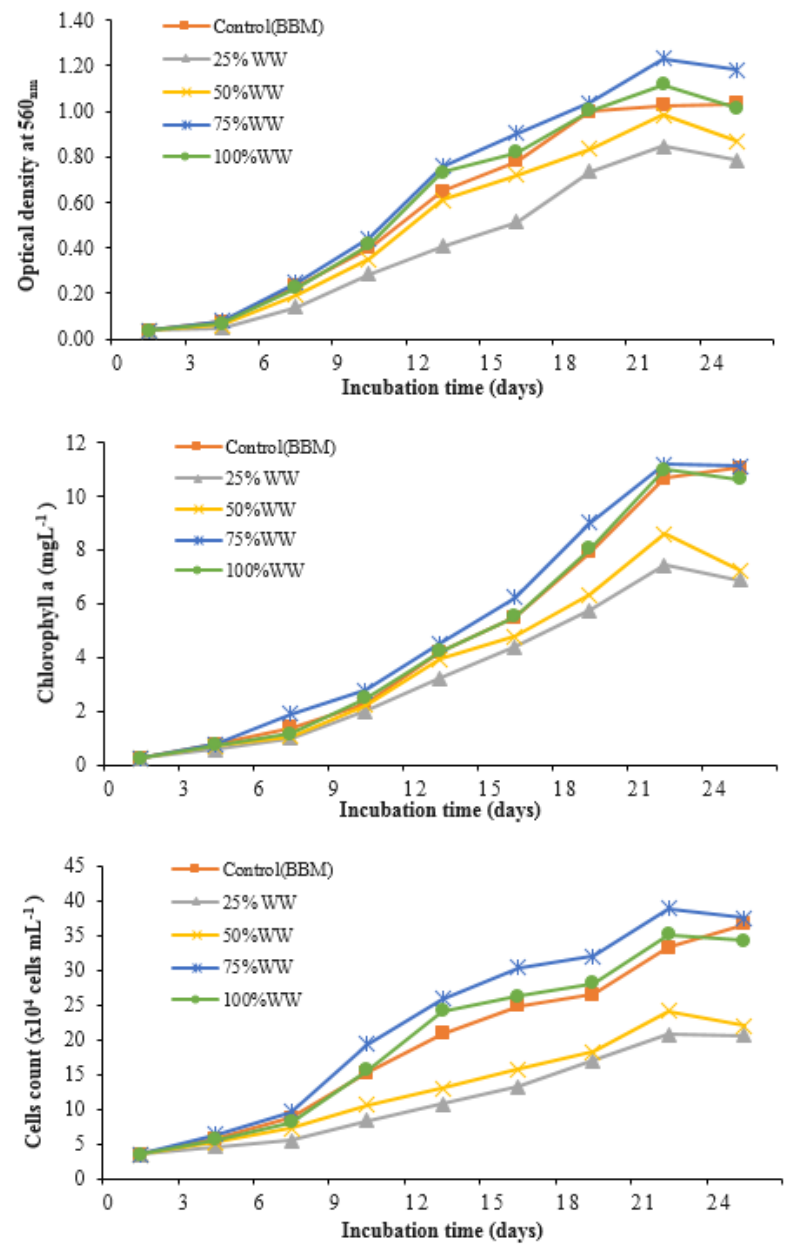

Figure 2

Growth curves of Asterarcys quadricellulare by monitoring of optical density, chlorophyll (a) and cells count grown for 24 days on control (BBM) and (25, 50, $75,100 \% W W$ ) 


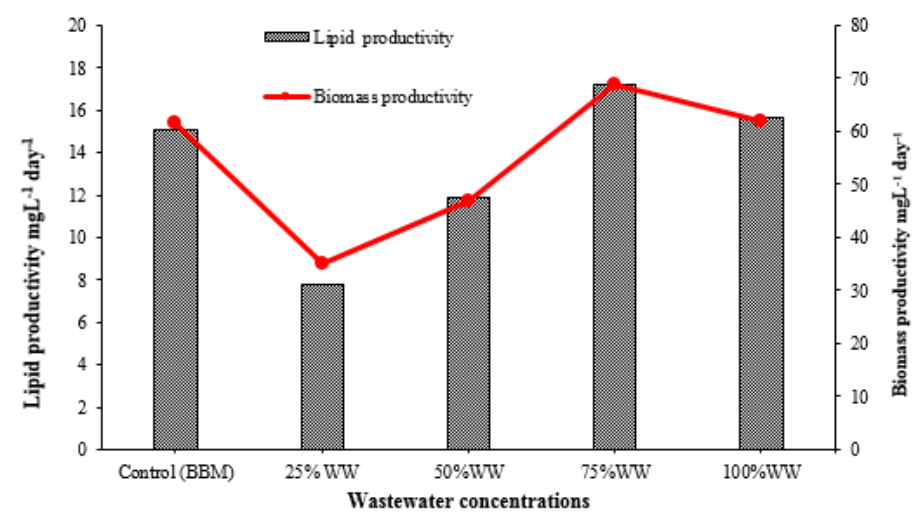

Figure 3

Biomass and lipid productivities of A. quadricellulare grown for 24 days on control and different municipal wastewater concentrations $(25 \%, 50 \%, 75 \%$ and $100 \%$ WW)

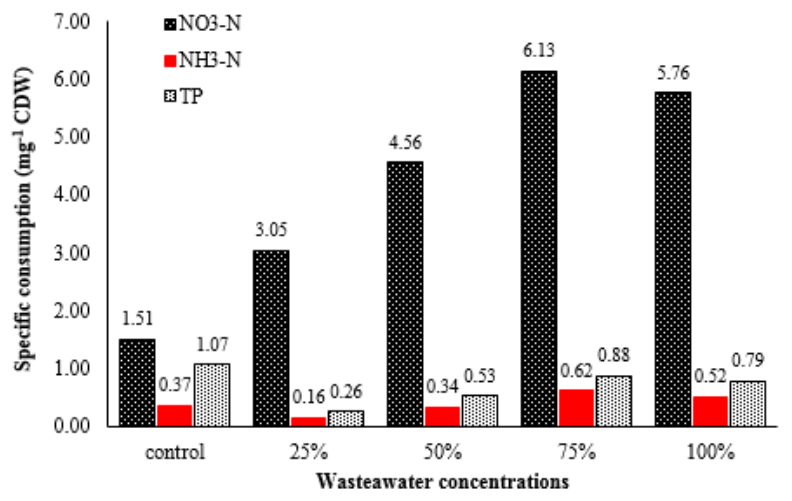

\section{Figure 4}

Specific consumption of nitrogen and phosphorous ( $\mathrm{mg} \mathrm{g}-1 \mathrm{CDW}$ ) by Asterarcys quadricellulare grown for 24 days on control and different concentrations of wastewater $(25 \%, 50 \%, 75 \%$ and $100 \% W W)$

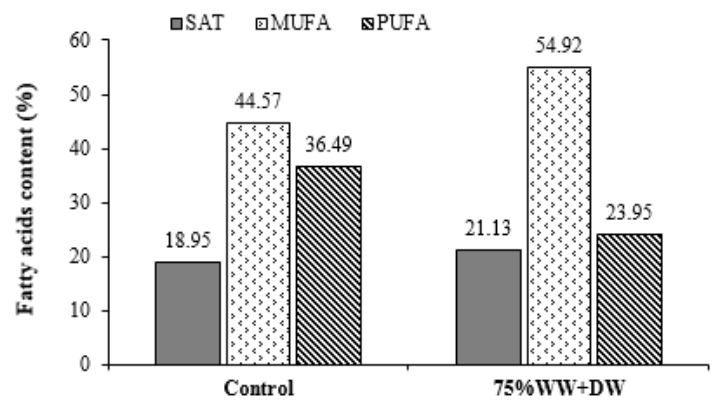

Figure 5

Fatty acids composition (SAT, MUFA, and PUFA) of Asterarcys quadricellulare grown in control BBM and $75 \%$ WW for 24 days 